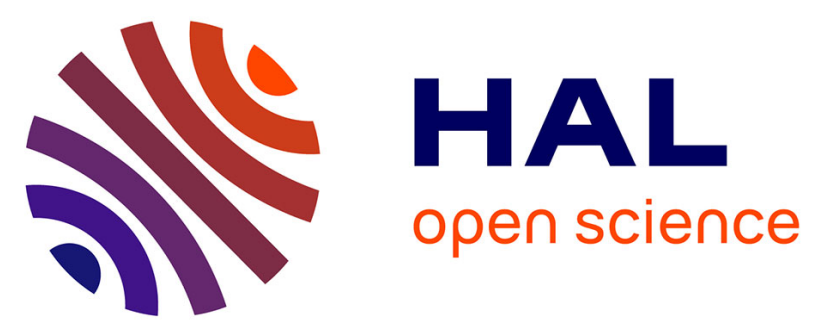

\title{
Beyond the Dichotomy between Natural and Knowledge Commons: Reflections on the IAD Framework from the Ubatuba Open Science Project
}

\author{
Sarita Albagli, Anne Clinio, Henrique Z M Parra, Felipe Fonseca
}

\section{To cite this version:}

Sarita Albagli, Anne Clinio, Henrique Z M Parra, Felipe Fonseca. Beyond the Dichotomy between Natural and Knowledge Commons: Reflections on the IAD Framework from the Ubatuba Open Science Project. ELPUB 2018, Jun 2018, Toronto, Canada. 10.4000/proceedings.elpub.2018.28 . hal01816671

\section{HAL Id: hal-01816671 \\ https://hal.science/hal-01816671}

Submitted on 15 Jun 2018

HAL is a multi-disciplinary open access archive for the deposit and dissemination of scientific research documents, whether they are published or not. The documents may come from teaching and research institutions in France or abroad, or from public or private research centers.
L'archive ouverte pluridisciplinaire HAL, est destinée au dépôt et à la diffusion de documents scientifiques de niveau recherche, publiés ou non, émanant des établissements d'enseignement et de recherche français ou étrangers, des laboratoires publics ou privés. 


\title{
Beyond the Dichotomy between Natural and Knowledge Commons: Reflections on the IAD Framework from the Ubatuba Open Science Project
}

\author{
Sarita Albagli, Anne Clinio, Henrique Parra and Felipe Fonseca
}

This work was funded by OCSDNet/IDRC/UKAid, Fundação Carlos Chagas de Apoio à Pesquisa do Estado do Rio de Janeiro (Faperj) e Conselho Nacional de Desenvolvimento Científico e Tecnológico (CNPq). We also thank the contributions of the reviewers.

\section{Introduction}

1 The paper presents a critical analysis of the possibilities and limits of the Institutional Analysis and Development (IAD) framework, proposed by Elinor Ostrom and researchers from Indiana School, specially addressing the mutual relations between natural and knowledge commons. It is based on the results of an action-research project on the role of open science (OS) in development, carried out in 2015-2017, as part of the Open and Collaborative Science in Development Network-OCSDNet ${ }^{1}$. Focusing on the institutional, political, and governance issues affecting knowledge production and circulation, the project provided the opportunity to observe how these dynamics take place in a relatively small-scale (while heavily interconnected) context-the municipality of Ubatuba, on the North Coast of the State of São Paulo, Brazil. Our study produced rich empirical and theoretical material for analysis, offering possibilities for critical reflection as well as social learning relevant to other territorial and social contexts (See Albagli et al., 2018).

Ubatuba is located in the Atlantic Rain Forest region, a strategic and vulnerable environmental area, with a high level of endangered socio-biodiversity, and a focus of 
intense scientific research. Ubatuba's key development challenges are related to how to conciliate:

a. its rich and strategic natural, cultural, and knowledge commons;

b. the necessity to provide access to local populations to social and economic benefits derived from the use of that wealth from a sustainable development perspective;

c. political empowerment of local communities in a context of inequality of access to institutional deliberation processes; and

d. the contributions that information and knowledge may make for these processes.

While most of the Ubatuba's territory (around 80\%) is located within the protected area of the State Park of Serra do Mar (PESM), its economy is based on seasonal and predatory tourism that encourages real estate speculation, as well as, more recently, oil exploration boosted since the pre-salt discoveries. These aspects characterize a highly contentious action arena regarding its natural and immaterial commons.

4 This paper presents a part of the research and it involved the following steps:

a. Systematizing the literature on the IAD framework, in order to understand its rationale and consider its possible uses (and limits) in our case study. We were particularly interested in understanding how this framework expanded to include knowledge commons as part of its analysis.

b. Mapping and selecting literature representative of other theoretical approaches to the concept of common(s) (Hardin, Bollier, Negri, Laval and Dardot, among others), observing their convergence and divergence with Ostrom's perspective.

c. Developing a two-way exercise. On the one hand, we mobilized aspects of the IAD framework as a toolkit to help us select and organise relevant information, to characterize our "action arena" and to define an "action situation", focusing on the local socio-institutional context, key actors and their (cooperative or conflictive) relationships. We expected this approach would be helpful to analyze our case, because: it opposes a path dependence perspective, giving place to future alternative scenarios; and it could be used to analyze dynamic and changing situations. On the other hand, we confronted the IAD framework with our empirical research results, also considering other interpretative approaches identified in previous steps.

5 At the end we observed that the relevance of IAD framework lies in the fact that the diffusion and adoption of open science is closely related to institutional issues (both formal and informal) that affect the open and collaborative nature of knowledge production and circulation. On the other hand, those issues are inextricably invested with conflicts and power relations over natural and immaterial commons. In this sense, it has also highlighted the mutual and contradictory relations between the new einfrastructures and the vulnerability/robustness of information and knowledge commons, which requires going beyond the access paradigm.

\section{The IAD framework and the commons}

6 The IAD framework was developed by Elinor Ostrom ${ }^{2}$ and other researchers of the Indiana School, based on extensive empirical research that demonstrated that a community can self-organize to "successfully" 3 use and manage a common pool resource (CPR) ${ }^{4}$ (Ostrom 1990). In other words, they argued that local and self-organized populations can economically exploit a CPR in a sustainable way for long periods of time. The IAD framework was first built on research on urban public goods, and it was further 
developed based on the work on the formal and informal rules that positively or negatively affect the sustainable management of natural CPRs (such as groundwater basins, irrigation systems, grazing systems, and forests). Ostrom team main question was: "[...] how a group of principals who are in an interdependent situation can organize and govern themselves to obtain continuing joint benefits when all face temptations to freeride, shirk, or otherwise act opportunistically?" (Ostrom, 1990, p. 29).

7 The results from the case studies helped them to question widely accepted theories-such as "The Tragedy of Commons" (Hardin, 1968), "The Prisoner's Dilemma" (Dawes, 19731977) and "The Logic of Collective Action" (Olson, 1965)-for whom individuals necessarily develop opportunistic behavior towards the maximum exploitation of common resources, putting individual profit above all, and disregarding the collective losses of overexploitation. According to those theories, predatory behavior is an inherent feature of collective management of common resources, which necessarily leads to their ruin. This would justify the prescription of either the privatization of the commons or the imposition of rules by the State. In all cases, those theories envisaged the necessity of an external authority to supervise the use of common resources either by limiting their access or by applying sanctions to those who violate the rules established to ensure longterm sustainability and productivity.

Commons were later defined as a general term referring to "a shared resource that is vulnerable to social dilemmas" (Ostrom \& Hess, 2007, p. 13), meaning: high vulnerability to subtraction (also referred to as rivalry, when the use of something by someone prevents its use by another one) and difficulty to exclude free riders (opportunistic behaviour) $)^{5}$. Ostrom and Hess did not differentiate common (singular) and commons (plural). For them, "Commons is an awkward word in the English language. The same word is used for both the singular and plural forms." (Ostrom \& Hess, 2007, p. 21). Other authors would argue that the distinction between these two terms is a significant point, as we will discuss later.

9 Ostrom and Hess focused on the institutional dimension-"the rules, decisions, and behaviors people make in groups in relation to their shared resource" (Ostrom \& Hess, 2007, p. 10). A set of eight "design principles" of institutional robustness in (un)successfully managing common-pool resources were pointed out (Ostrom, 1990), provided that they should not be seen in a prescriptive way, as models, but rather as "insightful findings in the analysis of small, homogeneous systems" (Ostrom \& Hess, 2007, p. 7). Their institutionalist approach emphasized rules-in-use (those practiced by actors) and "invisible" institutions (widely recognized sets of rules-in-use), as key aspects at times of institutional change. In this sense, institutions were conceived as "formal and informal rules that are understood and used by a community. [...] [They] are not automatically what is written in formal rules. They are rules that establish the working "do's and don'ts" for the individuals in the situation that a scholar wishes to analyze and explain" (Ostrom \& Hess, 2007, p. 42). Ostrom was particularly interested in developing a "microsituational level" of analysis and "more configural approaches", based on empirical work in order to confront "an immense diversity of situations in which humans interact", and to stress the importance of fitting policy prescription and institutional rules to specific social-ecological settings. "One-size-fits-all' policies are not effective." (Ostrom 2009, p. 409).

10 The authors also highlighted the role of informed and communicative patterns of interaction within the community as ways to develop a common language and a collective 
understanding of the use of common resources, elaborating norms on rights and duties in resource management and evaluating the cost-benefits of agreed rules. "With adequate information [participants] may develop increasing trust so that the situation can lead to productive outcomes" (Ostrom \& Hess, 2007, p. 59)

The IAD methodology was conceived as a "multitier conceptual map" (Ostrom, 2005) and a "metatheoretical language", designed "to enable scholars to analyze systems that are composed of a cluster of variables, each of which can then be unpacked multiple times depending on the question of immediate interest" (Ostrom, 2009, p. 414). It is organised in three clusters of variables schematically represented by Figure 2 . Depending on the research question, it is possible to privilege one of these clusters as the starting point of the analysis.

Figure 1: Institutional Analysis and Development Framework

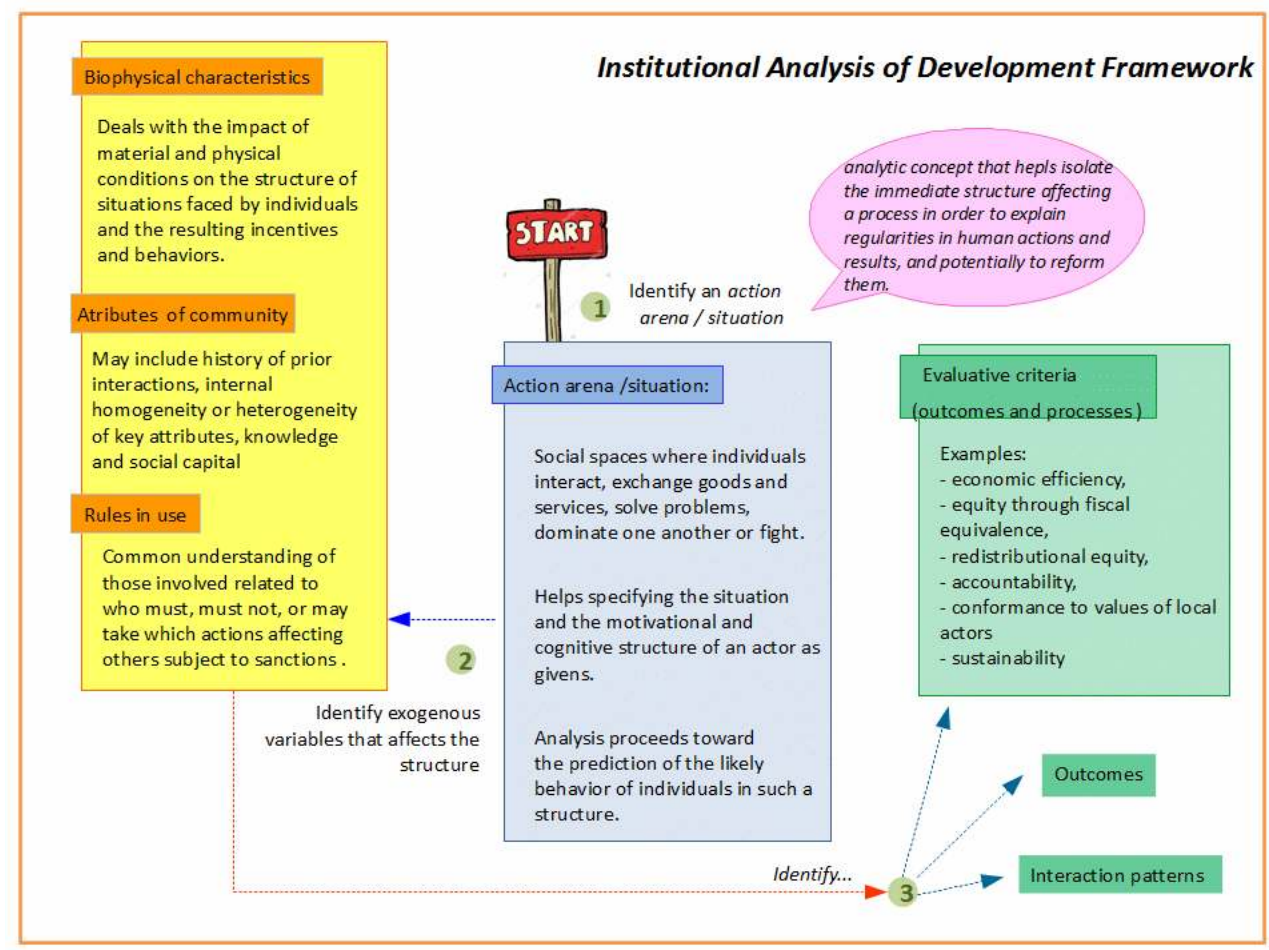

Adapted by Clinio (2017) from Ostrom (2010)

12 The action arena refers to "the social space where individuals interact, exchange goods and services, solve problems, dominate one another, or fight (among the many things that individuals do in action arenas)." (Ostrom, 2010, s.p). Action arenas include one or more action situations and the participants in those situations (Ostrom, 2005). The action situation, "enables an analyst to isolate the immediate structure affecting a process of interest to the analyst for the purpose of explain regularities in human actions and results, and potentially to reform them" (Ostrom, 2010, p. 286). Action arenas and action situations are considered to be at the core of the IAD framework and they are affected by a set of broadest categories of "external factors" (biophysical characteristics, attributes of the community, and rules in use). 


\section{Traditional and new commons}

13 Ostrom's initial focus on natural commons (Ostrom, 1990) was further expanded to the analysis of information and knowledge as "new commons" (Ostrom \& Hess, 2007). With the rise of distributed information and knowledge in digital form on the web, the concept of the commons helped "to conceptualize new dilemmas" (Ostrom \& Hess, 2007, p. 4), given the way new information and communication technologies have affected "how knowledge is managed and governed, including how it is generated, stored, and preserved" (Ostrom \& Hess, 2007, p. 9). Ostrom and Hess emphasized the fact that these new technologies can promote either "the robustness or vulnerability of a commons". For them, digital forms made knowledge "more vulnerable than ever before", enabling the "ability to capture the previously uncapturable" (Ostrom \& Hess, 2007, p. 10, 14).

When hard-copy journals, for instance, were sold to libraries and individuals, the decentralization of multiple copies made the works robust. When journals are in digital form and licensed to libraries or individuals, the works are centralized and vulnerable to the whims or happenstance of the publisher. (Ostrom \& Hess, 2007, p. 14)

Therefore the authors alerted to the importance of keeping the conditions for the preservation and sustainability of knowledge as a common good for present and future generations. They highlighted the emergence of scientific and social movements in favor of knowledge and information commons, as a central pillar of the struggle for democracy. On the other hand, they argued that "knowledge commons is not synonymous with open access", stressing their understanding that "a commons is a shared resource that is vulnerable to social dilemmas" (Ostrom \& Hess, 2007, p. 14).

The authors pointed out similarities and differences between knowledge and "traditional commons". Both were considered goods, resources jointly used and managed by groups at different levels and scales. For them, "the essential questions for any commons analysis are inevitably about equity, efficiency, and sustainability." (Ostrom \& Hess, 2007, pp. 6). On the other hand, they highlighted the cumulative character, the complex nature and the "dual functionality" of knowledge-"as a human need and an economic good", "both a social process and a deeply personal process". They advocated that the IAD framework could be "of value in understanding knowledge as a commons-in regard to both the public-good aspects of this commons and the common-pool resource aspects." (Ostrom \& Hess, 2007, p. 16).

Understood as global commons, neither a private nor a strict public resource, knowledge was defined as:

"all intelligible ideas, information, and data in whatever form in which it is expressed or obtained. [...] to all types of understanding gained through experience or study, whether indigenous, scientific, scholarly, or otherwise nonacademic. It also includes creative works, such as music and the visual and theatrical arts." (Ostrom \& Hess, 2007. pp. 7-8).

In this sense, Ostrom and Hess were not only referring to scholarly and scientific knowledge, but to more extended knowledge concepts and issues "far beyond the ivory tower." 


\section{Alternative views}

18 Alternative and complementary perspectives on the common(s) have been developed relative to that proposed by Ostrom and team. We summarize below those that address more directly the aspects that we want to emphasize here.

19 A first set of arguments refutes a rigid division between natural and intellectual commons, arguing that this distinction should rather be re-interpreted as a matter of emphasis in the analysis, considering the necessary dual character of the common (see Vieira, 2014). From this perspective, Hardt and Negri (2009, p. xviii) claim that their notion of the common "does not position humanity separate from nature, as either its exploiter or its custodian, but focuses rather on the practices of interaction, care, and cohabitation in a common world, promoting the beneficial and limiting the detrimental forms of the common.". In this sense, Massimo De Angelis (2007) recalls the contribution of historian Peter Linebaugh (2008) who popularized the term "commoning" as corresponding to "the (re)production of commons". David Bollier (2014, p. 351) also refers to Linebaugh when he states that "there is no common good without commoning", understood as "a set of ongoing practices, not an inert physical resource". He claims that "the commons is not only about shared resources; it's mostly about the social practices and values that we devise to manage them" (Bollier, 2014, p. 351).

A second set of arguments questions the idea of intrinsic characteristics of the commons, considering they are the result of collective and conflicting decisions and actions that promote or hamper practices that ensure their equitable and sustainable management. For Dardot and Laval (2015, p. 271),

Nothing is in itself or by nature "common". Ultimately it is social practices and only them that decide on the "common" character of a thing or a set of things. Therefore, against any naturalism or essentialism it is necessary to maintain that it is the activity of men which makes something a common, keeping it from any logic of appropriation and reserving it for collective use.

21 A third set of arguments criticizes the idea that more information leads to better politics as concealing the conflicts and inequalities within social relations. On the contrary, social actors usually diverge about expectations and objectives and hardly establish long-lasting agreements based on consensus and mutual truth. The conflicting dimension is an integral part of the commons and its governance. From this perspective, Dardot and Laval (2015, p. 271) argue that

The conflict dimension must be recognized as part of the common and not considered an unfortunate 'side effect' that should be avoided: the common it does not constitute itself, it does not perpetuate itself and it does not expand in any way other than in and through conflict. What is instituted as common is in active opposition to a privatization process (be it urban space, water or seeds).

Finally, Lafuente and Estalela (2015) developed a theoretical-conceptual approach in which common does not only mean common goods (the commons), referring to an economic sense. Common also-and mainly-refers to the relationship with otherness, "in between", in a more anthropological sense. From this perspective, they propose the notion of "common science", which combines knowledge activism and knowledge production, opening up science agenda, concepts and methods to the scrutiny and contribution of other epistemic groups. This mode of science acknowledges the epistemic value of the "experiential" as well as the ordinary knowledge. In this sense, lay people 
should be recognized as "experts in experience" (Callon \& Rabeharisoa, 2003) who produce relevant knowledge from solving problems in everyday life and from participating in social movements. Actors with differents points of view not only alter the social composition of science, but also promote alternative modes of knowledge. Lafuente (2012, p. 144) considers that it favors "more robust" decisions because "each new collective incorporated represents a lower degree of exclusion, implies an extension of freedoms, and, finally, makes visible an expanded society beyond the limits we believed to be insurmountable".

\section{A "situated" view from Ubatuba: possibilities and limits of the IAD framework}

Our case study on open science in the context of the municipality of Ubatuba helped us to identify both possibilities and limits in the use of the IAD framework in a concrete situation. Among the limits, we point out:

a. The difficulty in delimiting of a single common pool resource in that region, since our action arena is not restricted to the management of a single resource of common use, but it refers to a medley of resources.

b. The larger scale and heterogeneity of perspectives and interests of its population, which hinders trust relations and mutual agreement. While the IAD case studies reported by Ostrom and team encompass small-scale resource systems, usually involving communities with about 50 to 15,000 people who depend heavily on that resources for their livelihoods, Ubatuba municipality has a population of about 80 thousand inhabitants, in a heterogeneous composition and diverse interests and conflicts: indigenous communities, fishermen, caiçaras, quilombolas and a multitude of floating residents and seasonal tourists.

c. The difficulty to operationalize the IAD framework, since it requires information that is not easily available to the researcher, which would require an intense and prolonged fieldwork, broader than what was feasible for the project.

d. Finally, the fact that, as pointed by Vieira (2014), the IAD framework does not sufficiently address considerations about broader socio-political and economic relations and-long term historical processes, nor the analysis of power relations, conflicts and inequalities among actors with different expectations. In our case, the economic and territorial occupation through tourism, real estate, oil and gas industries place local dynamics in strong interaction and interdependence with broader scales (regional, national and global).

On the other hand, the IAD framework was useful to think of our research field as an action situation, in motion, a non-static reality, therefore quite consistent with our perspective of action research.

We defined as our action situation the process of revision of the ecological-economic zoning (EEZ) of the North Coast of São Paulo, which is a legal responsibility of the State Government. With the help of the Municipal Department of Environment, public hearings were held in the region, aiming to inform the population about the process and mobilize residents to draw up a plan in line with local demands. More than 80 requests for modifications were submitted by the municipal government, responding to demands submitted by the local population. The effort of the Traditional Communities Forum (FCT) to develop its own map to support the EEZ revision reveals the understanding that the role of information users is very limited for those who aim to interfere politically. These communities wish not only to contribute their accumulated experience and knowledge in 
the sustainable management of common resources but also to influence the decisions that affect them.

Nevertheless several local leaders reported problems in the traditional communities participation in the EEZ revision process. Our research evidenced that overlapping the roles of policy-makers and information providers is not mere coincidence. It is an essential strategy for data production that legitimates the arguments competing for the definitions of the EEZ and, in the end, disputing different conceptions and strategies of development. In this process, scientific knowledge, produced in research institutes, universities and laboratories, is mobilized by public policymakers with the purpose of certifying and, therefore, legitimating their proposals. In this sense, the mastery of technical language and the ability to translate this knowledge into information represented in maps - and, even more so, in rules-in-form-is an important advantage for policymakers.

We concluded that the role assigned to information and knowledge, from different points of view and strategies, lies at the heart of disputes between a managerial logic that also implies the normalization of new forms of control versus a logic of dissent that disputes the criteria of "measure" of instrumental reason and defines new instituting forms of the common. And this represents the opposite of the idea of an "institutional robustness" based on the co-construction of rules-in-use involving different actors and perspectives. At the end, the perpetuation of the commons depends on the ability of actors to evolve rules and to build democratic ways to dispute antagonistic views.

These findings are congruent with the criticisms of the open science initiatives focused only on "access", since they may reinforce the equivalence between a "well informed" policy and a "certified" one. In this sense, we adopted the notion of common science, proposed by Lafuente and Estalella (2015), emphasizing the importance of favoring the interlocution of science with other cognitive actors and their knowledge bases.

Finally, the IAD framework served us as an analytical tool that was instrumental in dealing with different variables and dimensions. Congruent with our territorial perspective, the IAD framework made us critically interrogate about the mutual feedback between natural (or more widely, material) and knowledge/information commons. Nevertheless, When in our action research project, we aimed not only to combine, on the one hand, the IAD framework's initial focus on the collective management of natural commons, and, on the other, the latter one oriented to the knowledge commons. We proposed to reflect on the interaction and co-determination between these two common resources. Moreover, we shed light on the fact that they are not just two different types of commons, but are mainly two dimensions of the same "commoning" process.

\section{Concluding remarks}

30 From the outset of our project, we questioned the current idea in the open science movement that open access to scientific information would be capable or be sufficient to reduce asymmetries and promote "better informed" and more egalitarian policies. We observed that, although democratization in access to information and knowledge-and even the recognition of the contribution of different modes of knowledge-is important, this does not solve the asymmetries of power over common pool resources. The disputes 
over the natural commons and the information and knowledge commons are part of a local institutional dynamics characterized by:

1. the flow of public, private and non-governmental interests through different spaces, within an informal network of influence;

2. the existence of a complex movement of alliances and tensions between actors and their different institutional positions;

3. the diversity of forms of information and knowledge production and demands as a central aspect of the positioning of the actors in affirming and defending their views and claims with respect to the commons.

31 In this sense, we adopted a substantive socio-territorial approach, relying on the Brazilian geographer Milton Santos's conception of space as a hybrid made up of the indissociable union of systems of objects and systems of actions (Santos, 1996, Albagli, 2017). The sustainable and equitable management of the local natural resources as a commons is inextricably co-related to the disputes over the production and circulation of knowledge and information as a commons. The production of knowledge commons involves the social appropriation of the territory, as well as a common material base, composed of natural and artificial goods that support life in common. On the other hand, the so-called "exogenous" variables in the IAD framework-biophysical characteristics, attributes of the community, and rules-in-use-are an intrinsic part of an action situation. Our common science approach, based on Lafuente and Estalela (2015), implied the recognition that a pluralistic ecosystem of knowledge modes is closely related to a pluralistic ecosystem of modes of existence (Albagli, Parra, Fonseca, \& Maciel, 2018). From this perspective, in our case, we considered the territory as the very infrastructure of the production and reproduction of knowledge common, both as the material basis of life in common and as the space where modes of subjectivation for the commoning takes place.

\section{BIBLIOGRAPHY}

\section{References}

Albagli, S. (2017). “Technical-Scientific-Informational Milieu, Networks and Territories.” In L. Melgaço, C. Prouse, Carolyn (Ed.) Milton Santos: A Pioneer in Critical Geography from the Global South, 33-43. London: Springer International Publishing.

Albagli, S., Parra, H., Fonseca, F., \& Maciel, M.L. (2018). “Open Science and social change: a case study in Brazil." In L.Chan (Ed.) Contextualizing and Situating Openness: Understanding the Diversity and Contexts of Open Science in Development. University of Ottawa Press.

Angeli, M.D. (2006). "Introduction.” The Commoner. n. 11. Available at http://

www.commoner.org.uk/?p=24. Access on April 4, 2018.

Bollier, D. (2014). Think Like a Commoner: A Short Introduction to the Life of the Commons. Gabriola Island: New Society Publishers. 
Callon, M., \& Rabeharisoa, V. (2003). "Research 'in the wild' and the shaping of new social identities." Technology in Society, v. 25: 193-204.

Clinio, A. (2017). Reflections on the Application of the IAD Framework to analyze the Ubatuba Open Science Platform. Blog post published at OSCDNet website. Available at http://ocsdnet.org/ reflections-on-the-application-of-the-institutional-analysis-and-development-iad-framework-toanalyze-the-ubatuba-open-science-platform/. Access March, 29, 2018.

Dardot, P., Laval, C. (2015). "Propriedade, apropriação social e instituição do comum.” (Tradução do francês de Naira Pinheiro dos Santos). In Tempo Social, revista de sociologia da USP, v. 27, n. 1. Available at http://www.scielo.br/pdf/ts/v27n1/0103-2070-ts-27-01-00261.pdf. Access 18 March, 2018.

Lafuente, A. (2012). “Modernización epistémica y sociedad expandida." In R. Diaz (Ed). Educación expandida. Sevilla: Zemos98. Available at http://hdl.handle.net/10261/56386 Access 27 Dec, 2015.

Lafuente, A., \& Estalella, A. (2015). "Ways of science: public, open, and commons." In S. Albagli, S., M.L. Maciel, \& A.H. Abdo (Eds). Open Science, open issues. Brasília: Ibict, Rio de Janeiro: Unirio.

Laval, C., \& Dardot, P. (2014). Común: Ensayo sobre la revolución en el siglo XXI. Barcelona: Editorial Gedisa.

Hardin, G. (1968). “The tragedy of commons.” Science Magazine.

Hardt, M., Negri, A. (2009). Commonwealth. Cambridge: The Harvard University Press.

Linebaugh, P. (2008). The Magna Carta Manifesto: Liberties and Commons for All. Berkeley: University of California Press.

Ostrom, E. (1990). Governing the Commons: The Evolution of Institutions for Collective Action. Cambridge University Press.

Ostrom, E. (2005). Understanding institutional diversity. Princeton: Princeton University Press. Ostrom, E., Hess, C. (2007). Understanding Knowledge as a Commons: From Theory to Practice. The MIT Press.

Ostrom, E (2009). Beyond Markets and States: Polycentric Governance of Complex Economic Systems, Prize Lecture, December 8, 2009.

Ostrom, E. (2010). "Institutional Analysis and Development: Elements of The Framework in Historical Perspective." In Crothers, C. (Ed). Historical Developments and Theoretical Approaches in Sociology, vol. II. Encyclopedia of Life Support Systems Publishers \& Unesco, Singapura.

Santos, M. (1997). A Natureza do Espaço: Técnica e Tempo. Razão e Emoção. São Paulo: Hucitec.

Vieira, M.S. (2014). Os bens comuns intelectuais e a mercantilização. Tese (doutorado). Faculdade de Educação, Universidade de São Paulo: São Paulo.

\section{NOTES}

1. See https://ocsdnet.org/projects/ibict-instituto-brasileiro-de-informacao-em-ciencia-etecnologia-okbr-open-knowledge-brasil-participating-institution/ and http:// cienciaaberta.ubatuba.cc/

2. In 2009, Ostrom shared the Nobel Memorial Prize in Economic Sciences with Oliver E. Williamson for "her analysis of economic governance, especially the commons" (Wikipedia). 
3. For Ostrom, the notion of "successful" management of common goods refers to the twofold objective of (1) avoiding overexploitation and exhaustion of resources, and (2) generating quality of life, understood here as the effective people's participation in the management of the common goods through principles of coexistence shared by all involved.

4. "[...] it refers to a natural or man-made resource system that is sufficiently large as to make it costly (but not impossible) to exclude potential beneficiaries from obtaining benefits from its use." (Ostrom, 1990, p. 30).

5. Vincent and Elinor Ostrom's (1977) previous work had typified four kinds of goods-public goods, toll or club goods, common-pool resources, and private goods, classified according to their level of exclusion (easy, difficult) and subtractability (low, high).

6. “[...] cada nuevo colectivo incorporado representa un grado menor de exclusión, implica un ensanchamiento de las libertades y, por fin, hace viable una sociedade expandida más allá de los límites que creíamos infranqueables."

\section{ABSTRACTS}

The paper presents a critical analysis of the possibilities and limits of the Institutional Analysis and Development (IAD) framework, proposed by Elinor Ostrom and team, specially addressing the mutual relations between natural and knowledge commons. It results from an actionresearch project on the role of open science (OS) in development, carried out in the municipality of Ubatuba, on the North Coast of the State of São Paulo, Brazil, in 2015-2017. The work involved: systematizing the literature on the IAD framework; mapping and selecting literature representative of other theoretical and conceptual approaches; critically using and adapting the framework to the case studied. The project provided the opportunity to observe how these dynamics take place in a relatively small-scale (while heavily interconnected) context. While the IAD framework helped us to analyse the institutional, political, and governance issues affecting knowledge production and circulation, we observed the higher complexity of our action arena, shedding light on the fact that natural and knowledge commons are the two dimensions of the same "commoning" process.

\section{INDEX}

Keywords: Commons, Open Science, Institutional Analysis and Development, Ubatuba, Brazil

\section{AUTHORS}

\section{SARITA ALBAGLI}

Institute of Information in Science and Technology, IBICT-Brazilian, Brazil

sarita.albagli@gmail.com

(corresponding author) 


\section{ANNE CLINIO}

Liinc-Interdisciplinary Laboratory of Information and Knowledge Studies, Brazil anneclinio@gmail.com

\section{HENRIQUE PARRA}

Unifesp-Federal University of São Paulo, Brazil

opensocialsciences@gmail.com

\section{FELIPE FONSECA}

Ubalab, Brazil

felipefonseca@gmail.com 